\title{
Calcium Hydroxide Increases Human Umbilical Cord Mesenchymal Stem Cells Expressions of Apoptotic Protease-Activating Factor-I, Caspase-3 and Caspase-9
}

This article was published in the following Dove Press journal:

Clinical, Cosmetic and Investigational Dentistry

\author{
Eric Priyo Prasetyo ${ }^{1,2}$ \\ Mefina Kuntjoro ${ }^{1,3}$ \\ Setyabudi Goenharto ${ }^{2}$ \\ Devi Eka Juniarti ${ }^{2}$ \\ Febriastuti Cahyani $^{2}$ \\ Nike Hendrijantini ${ }^{3}$ \\ Alexander Patera Nugraha ${ }^{4}$ \\ Ninuk Hariyani ${ }^{5}$ \\ Fedik Abdul Rantam (1D ${ }^{6,7}$ \\ 'Doctoral Program, Faculty of Medicine, \\ Universitas Airlangga, Surabaya, \\ Indonesia; ${ }^{2}$ Department of Conservative \\ Dentistry, Faculty of Dental Medicine, \\ Universitas Airlangga, Surabaya, \\ Indonesia; ${ }^{3}$ Department of \\ Prosthodontics, Faculty of Dental \\ Medicine, Universitas Airlangga, Surabaya, \\ Indonesia; ${ }^{4}$ Department of Orthodontics, \\ Faculty of Dental Medicine, Universitas \\ Airlangga, Surabaya, Indonesia; \\ ${ }^{5}$ Department of Dental Public Health, \\ Faculty of Dental Medicine, Universitas \\ Airlangga, Surabaya, Indonesia; ${ }^{6}$ Stem Cell \\ Research and Development Center. \\ Universitas Airlangga, Surabaya, \\ Indonesia; 'Laboratory of Virology, \\ Department of Microbiology and \\ Immunology, Faculty of Veterinary \\ Medicine, Universitas Airlangga, Surabaya, \\ Indonesia
}

Correspondence: Eric Priyo Prasetyo Department of Conservative Dentistry, Faculty of Dental Medicine, Universitas Airlangga, Jalan Mayjend Prof.

Dr. Moestopo 47, Surabaya, Indonesia

$\mathrm{Tel} / \mathrm{Fax}+62$ 3I 5030255

Email eric-p-p@fkg.unair.ac.id
Purpose: Calcium hydroxide is a gold standard dental material generally used for pulpal and periapical therapy including regenerative endodontic procedures because of its positive properties. However, evaluation about this material on stem cells is limited. Human umbilical cord mesenchymal stem cells (HUCMSCs) are potential to be used in regenerative therapy. Regenerative therapy needs a sustainable cell supply to maintain its regenerative capacity. The aim of this study was to ascertain the apoptosis result of calcium hydroxide on HUCMSCs through the expression of apoptotic protease-activating factor-1 (APAF-1), caspase-3, and caspase-9.

Materials and Methods: This study used a thawed frozen stock of passage 5 HUCMSCs, grown in minimum essential medium (MEM) alpha containing calcium hydroxide at concentration of 0.1 microgram $/ \mathrm{mL}$ for 1,3 and 7 days. Polyclonal antibody with fluorescence isothiocyanate (FITC) label was used to evaluate the expressions. APAF-1, caspase-3, and caspase- 9 expressions were recorded and compared on every observation day using fluorescence microscope. Analysis of variance was performed to analyze the significance among the results of treatment groups. The results were concluded significant if $\mathrm{p}<0.05$.

Results: The addition of calcium hydroxide in MEM alpha medium increases HUCMSCs expression of APAF-1, caspase-3 and caspase-9 significantly, compared to the control group without calcium hydroxide $(\mathrm{p}<0.05)$ in all the times. Day 1 showed the lowest increase followed by higher expressions on day 3 and day 7 .

Conclusion: HUCMSCs express increased APAF-1, caspase- 3 and caspase- 9 after in-vitro calcium hydroxide exposure. This should be considered when using calcium hydroxide on HUCMSCs for regenerative procedures with regard to other positive properties.

Keywords: apoptosis, calcium hydroxide, caspases, mesenchymal stem cells, umbilical cord

\section{Introduction}

Mesenchymal stem cells (MSC) are the most commonly used for regenerative therapy. These cells can easily be isolated, transplanted and It has the capacity of immune regulatory, self-renewal and differentiation into many cell types, such as osteocyte, neurons, adipocyte and chondrocyte. ${ }^{1}$ Human umbilical cord mesenchymal stem cells (HUCMSCs) are MSC derived from Wharton's jelly. HUCMSCs may be an appealing contender for application in periapical, pulpal, and alveolar bone regeneration. ${ }^{2}$ With regard to other adult stem cell sources, HUCMSCs are 
primordial, involving non-invasive collection method, higher differentiation capacity, immunosuppressive, immune privileged, and rich in stemness characteristics. ${ }^{3,4}$

Calcium hydroxide has been used in a number of treatment protocols in endodontics, including interappointment dressing, pulp capping agents, and root canal sealers. ${ }^{5}$ Calcium hydroxide is a vital alkaline substance administered in a favorable protocol of regenerative therapy. ${ }^{6}$ Calcium hydroxide may supply calcium ions that are necessary in the outset of intrinsic apoptotic pathway.

Stem cell availability and sustainability is important for the regenerative process in regenerative procedures, including regenerative endodontic procedures. The availability and persistence of HUCMSCs can be affected by programmed cell death or apoptosis. Previous study showed that stem cells reactions may vary based on time variation of contact towards the presence of calcium hydroxide. ${ }^{7}$ Apoptosis is crucial for tissue development and regeneration. ${ }^{8}$ Apoptotic protease-activating factor-1 (APAF-1), caspase-3, and caspase-9 are among prominent markers for apoptosis. In order to understand the effect of calcium hydroxide on HUCMSCs' survival, we observed the expression of these apoptotic biomarkers on HUCMSCs. Therefore, the aim of this study was to explore the expression of apoptotic protease-activating factor-1 (APAF-1), caspase-3, and caspase-9 on HUCMSCs after continuous contact with calcium hydroxide for 1 day, 3 days, and 7 days period in vitro. The hypothesis of this study is calcium hydroxide would increase apoptotic protease-activating factor-1 (APAF1), caspase-3, and caspase-9 expressions on HUCMSCs after continuous contact for 1 day, 3 days, and 7 days period in vitro.

\section{Materials and Methods}

\section{Preparation of HUCMSCs and Calcium Hydroxide}

Ethical clearance for this study was given by the Commission of Ethical Clearance for Health Research from Faculty of Dental Medicine Universitas Airlangga, Surabaya, Indonesia (No. 059/HRECC.FODM/II/2020). This study was conducted following ethical standards of experiments. The cell donors provided informed consent, in accordance with the Declaration of Helsinki. Frozen HUCMSCs stock from passage 5 was supplied by the Stem Cell Research and Development Center Universitas
Airlangga, Surabaya, Indonesia. This frozen stock was previously isolated and characterized.

HUCMSCs was confirmed previously by conducting flow cytometric check utilizing FACS Calibur (BD Biosciences, USA) for specific antibodies purchased from Becton-Dickinson (BD Biosciences, USA) for positive CD73, CD90, CD105, and negative CD45 and CD34. This fluorescence activated cell sorter (FACS) instrument was utilized to count the fluorescence intensity expressed by the cells. ${ }^{9,10}$ Frozen stock of passage 5 HUCMSCs was taken from minus $80^{\circ} \mathrm{C}$ cold storage and thawed by water bathing. After thawing, HUCMSCs were transported to other container with $10 \mathrm{~mL}$ minimum essential medium (MEM) alpha (Gibco, UK) at $37^{\circ} \mathrm{C}$ and centrifuged until they formed a cell pellet at $1600 \mathrm{rpm}$ for 5 minutes. The cell pellet was resuspended in $12 \mathrm{~mm}$ culture plate containing MEM alpha medium and stored in incubator for several hours at $37^{\circ} \mathrm{C}$. The thawed HUCMSCs were expanded and ready to be used for further study. ${ }^{11}$

Calcium hydroxide was obtained by combining minimum essential medium alpha (Gibco, UK) with the powder (EMSURE Merck, Germany). Calcium hydroxide concentration of $0.1 \mathrm{microgram} / \mathrm{mL}$ was used in this experiment.

\section{Evaluation of Apoptosis}

HUCMSCs were assigned into 9 groups of control and 9 groups of calcium hydroxide treatment, with allocation for 1 , 3 , and 7 days of observations. Each group consisted of six wells of M24 plate (Iwaki Asahi, Japan). Every M24 plate well was seeded with 250.000 HUCMSCs in $1 \mathrm{~mL}$ media. HUCMSCs in the treatment groups were grown in minimum essential medium (MEM) alpha containing 0.1 microgram/ $\mathrm{mL}$ calcium hydroxide, and the control groups were grown in MEM alpha medium only without the addition of calcium hydroxide. The groups were cultured in incubator at $37^{\circ} \mathrm{C}$ and $5 \% \mathrm{CO}_{2}$ and observed for 1, 3, and 7 days.

Apoptosis reaction of HUCMSCs was investigated through the expressions of apoptotic protease-activating factor-1 (Bioss Antibodies, USA), Caspase-3 (Bioss Antibodies, USA), and Caspase-9 (Bioss Antibodies, USA). The investigation was done following the manufacturer's instructions Other previous study used flow cytometric analysis for assessments. ${ }^{12}$ In this research APAF-1, Caspase-3, and Caspase-9 expressions were assessed for apoptosis using polyclonal antibody with fluorescence isothiocyanate (FITC) label (Bioss Antibodies, USA). Observation of the results was done with fluorescence 
microscope (Olympus, Japan) with imaging system at 100x magnification and processed in ImageJ software for fluorescence quantification (National Institute of Health, USA). ${ }^{13}$

\section{Statistical Analysis}

The evaluation was conducted in triplicates. Data were expressed as mean \pm standard deviation from the experiment. The data were checked for normal distribution. $T$-test was carried out for comparisons between treatment and control groups. One-way analysis of variance (ANOVA) was used for comparisons of three groups among day 1, 3, and 7 on each expression. Difference among groups was appraised significant if $P<0.05$.

\section{Results}

Mean and standard deviation (SD) of APAF-1, Caspase-3, and Caspase-9 expressions from HUCMSCs in control groups and calcium hydroxide groups is available on Table 1. Calcium hydroxide increase APAF-1 expression, corresponds to the days observed (Figure 1). APAF-1 expression was low on day 1 of both control and calcium hydroxide groups. Both control and calcium hydroxide groups showed significant increase $(p<0.05)$ from day 1 to day 3 , and then the calcium hydroxide group increase significantly on day 7 compared to the control group. There was a significant increase of APAF-1 expression on both the control and calcium hydroxide treatment groups from day 1 to day 3 , and from day 3 to day $7(p<0.05)$. Significance ( $p$ value) among exposure day in the control groups and calcium hydroxide groups on APAF-1 expression is available in Table 2.

Calcium hydroxide increase caspase- 3 expression, corresponds to the days observed (Figure 1). Caspase-3 expression of the control group was low on day 1 , day 3 , and day 7 .

Table I Mean and Standard Deviation (SD) of APAF-I, Caspase3, and Caspase-9 Expressions from HUCMSCs in Control Groups and Calcium Hydroxide Groups

\begin{tabular}{|c|c|c|c|}
\hline $\begin{array}{l}\text { Groups and } \\
\text { Exposure Days }\end{array}$ & $\begin{array}{l}\text { Expression of } \\
\text { APAF-I } \\
\text { Mean } \pm \text { SD }\end{array}$ & $\begin{array}{l}\text { Expression of } \\
\text { Caspase-3 } \\
\text { Mean } \pm \text { SD }\end{array}$ & $\begin{array}{l}\text { Expression of } \\
\text { Caspase- } 9 \\
\text { Mean } \pm \text { SD }\end{array}$ \\
\hline Control Day I & $1.5227 \pm 0.40756$ & $1.3200 \pm 0.29311$ & $1.3200 \pm 0.27310$ \\
\hline Control Day 3 & $14.8600 \pm 0.57280$ & $3.5400 \pm 0.58522$ & $11.6800 \pm 1.27915$ \\
\hline Control Day 7 & $15.3100 \pm 0.61397$ & $2.0600 \pm 0.21517$ & $28.0200 \pm 1.99328$ \\
\hline $\begin{array}{l}\text { Calcium hydroxide } \\
\text { Day I }\end{array}$ & $3.8247 \pm 0.96960$ & $1.6100 \pm 0.33143$ & $1.5567 \pm 0.33949$ \\
\hline $\begin{array}{l}\text { Calcium hydroxide } \\
\text { Day } 3\end{array}$ & $18.8913 \pm 3.91792$ & $31.8260 \pm 9.04446$ & $29.7520 \pm 6.08016$ \\
\hline $\begin{array}{l}\text { Calcium hydroxide } \\
\text { Day } 7\end{array}$ & $24.8733 \pm 5.34421$ & $31.2267 \pm 5.14817$ & $30.9620 \pm 4.22264$ \\
\hline
\end{tabular}

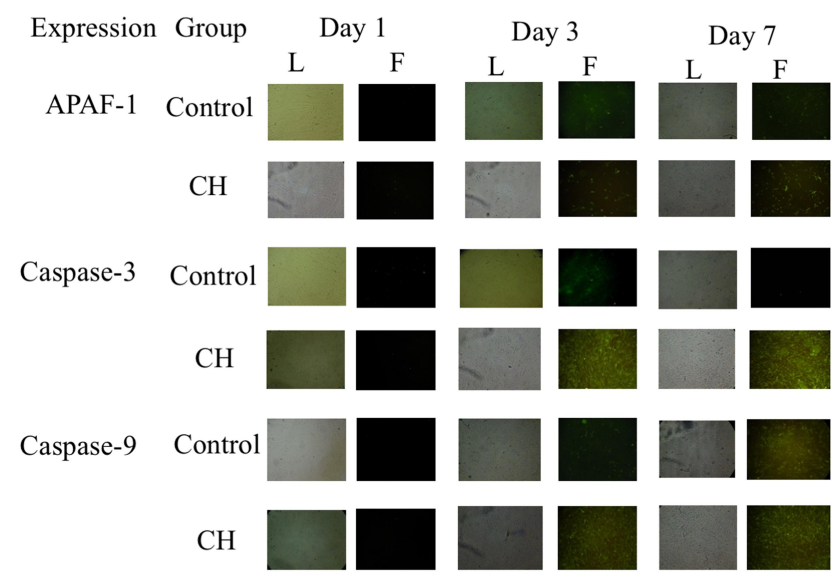

Figure I HUCMSCs culture seen under light microscope $(L)$ and fluorescence microscope (F) showing the expressions of APAF-I, Caspase-3, and Caspase-9 observed on day I, day 3 , and day 7 between control groups and calcium hydroxide $(\mathrm{CH})$ groups.

Caspase-3 expression of calcium hydroxide group increase significantly on day 3 and then slightly decrease on day 7 (there was no significant decrease $(p>0.05)$ between day 3 and day 7). There was no significant difference of Caspase-3 expression on day 1 . There was significant difference between the control groups and calcium hydroxide groups on day 3 and day $7(p<0.05)$. Significance ( $p$ value) among exposure day in the control groups and calcium hydroxide groups on caspase- 3 expression is available in Table 3.

Calcium hydroxide increase Caspase- 9 expression, corresponds to the days observed (Figure 1). Caspase-9 expression of both the control groups and calcium hydroxide groups were low on day 1 . The control group showed a gradual increase from day 1 to day 7. The calcium hydroxide groups revealed a significant increase of Caspase- 9 on day 3 and then quite steady on day 7 without significance $(p>0.05)$. Significance ( $p$ value) among exposure day in the control groups and calcium hydroxide groups on caspase- 9 expression is available in Table 4.

\section{Discussion}

There are many sources of mesenchymal stem cells. Among other stem cells, HUCMSCs is prominent because the isolation process is non-invasive and they can be expanded in large quantities. ${ }^{14}$ HUCMSCs and its application in regenerative dental procedures are limited. In this study, the HUCMSCs are according to standardization of MSCs cluster of differentiation surface markers and morphology. ${ }^{15}$ The HUCMSCs were grown in minimum essential medium alpha with and without the addition of calcium hydroxide, under normal culture condition. MTT assay was used in this study to measure cell viability under the effect of calcium 
Table 2 Significance ( $P$-value) Among Exposure Day in the Control Groups and Calcium Hydroxide Groups on APAF-I Expression

\begin{tabular}{|l|l|l|l|l|l|l|}
\hline $\begin{array}{l}\text { Groups and Exposure Day on } \\
\text { APAF-I Expression }\end{array}$ & $\begin{array}{l}\text { Control } \\
\text { Day I }\end{array}$ & $\begin{array}{l}\text { Control } \\
\text { Day 3 }\end{array}$ & $\begin{array}{l}\text { Control } \\
\text { Day 7 }\end{array}$ & $\begin{array}{l}\text { Calcium } \\
\text { Hydroxide Day I }\end{array}$ & $\begin{array}{l}\text { Calcium } \\
\text { Hydroxide Day 3 }\end{array}$ & $\begin{array}{l}\text { Calcium } \\
\text { Hydroxide Day 7 }\end{array}$ \\
\hline Control Day I & - & $0.000^{*}$ & $0.000^{*}$ & $0.000^{*}$ & - & - \\
Control Day 3 & $0.000^{*}$ & - & $0.027^{*}$ & - & $0.00 I^{*}$ & - \\
Control Day 7 & $0.000^{*}$ & $0.027^{*}$ & - & - & - & $0.000^{*}$ \\
Calcium hydroxide Day I & $0.000^{*}$ & - & - & - & $0.000^{*}$ & $0.000^{*}$ \\
Calcium hydroxide Day 3 & - & $0.00 I^{*}$ & - & $0.000^{*}$ & - & $0.000^{*}$ \\
Calcium hydroxide Day 7 & - & - & $0.000^{*}$ & $0.000^{*}$ & $0.000^{*}$ & - \\
\hline
\end{tabular}

Note: *Significant $(P<0.05)$.

Table 3 Significance ( $P$-value) Among Exposure Day in the Control Groups and Calcium Hydroxide Groups on Caspase-3 Expression

\begin{tabular}{|l|l|l|l|l|l|l|}
\hline $\begin{array}{l}\text { Groups and Exposure Day on } \\
\text { Caspase-3 Expression }\end{array}$ & $\begin{array}{l}\text { Control } \\
\text { Day I }\end{array}$ & $\begin{array}{l}\text { Control } \\
\text { Day 3 }\end{array}$ & $\begin{array}{l}\text { Control } \\
\text { Day 7 }\end{array}$ & $\begin{array}{l}\text { Calcium } \\
\text { Hydroxide Day I }\end{array}$ & $\begin{array}{l}\text { Calcium } \\
\text { Hydroxide Day 3 }\end{array}$ & $\begin{array}{l}\text { Calcium } \\
\text { Hydroxide Day 7 }\end{array}$ \\
\hline Control Day I & - & $0.000^{*}$ & $0.000^{*}$ & $0.017^{*}$ & - & - \\
Control Day 3 & $0.000^{*}$ & - & $0.000^{*}$ & - & $0.000^{*}$ & - \\
Control Day 7 & $0.000^{*}$ & $0.000^{*}$ & - & - & - & $0.000^{*}$ \\
Calcium hydroxide Day I & $0.017^{*}$ & - & - & - & $0.000^{*}$ & $0.000^{*}$ \\
Calcium hydroxide Day 3 & - & $0.000^{*}$ & - & $0.000^{*}$ & - & 0.786 \\
Calcium hydroxide Day 7 & - & - & $0.000^{*}$ & $0.000^{*}$ & 0.786 & - \\
\hline
\end{tabular}

Note: *Significant $(P<0.05)$.

Table 4 Significance ( $P$-value) Among Exposure Day in the Control Groups and Calcium Hydroxide Groups on Caspase-9 Expression

\begin{tabular}{|l|l|l|l|l|l|l|}
\hline $\begin{array}{l}\text { Groups and Exposure Day on } \\
\text { Caspase-9 Expression }\end{array}$ & $\begin{array}{l}\text { Control } \\
\text { Day I }\end{array}$ & $\begin{array}{l}\text { Control } \\
\text { Day 3 }\end{array}$ & $\begin{array}{l}\text { Control } \\
\text { Day 7 }\end{array}$ & $\begin{array}{l}\text { Calcium } \\
\text { Hydroxide Day I }\end{array}$ & $\begin{array}{l}\text { Calcium } \\
\text { Hydroxide Day 3 }\end{array}$ & $\begin{array}{l}\text { Calcium } \\
\text { Hydroxide Day 7 }\end{array}$ \\
\hline Control Day I & - & $0.000^{*}$ & $0.000^{*}$ & $0.045^{*}$ & - & - \\
Control Day 3 & $0.000^{*}$ & - & $0.000^{*}$ & - & $0.000^{*}$ & - \\
Control Day 7 & $0.000^{*}$ & $0.000^{*}$ & - & - & - & $0.024^{*}$ \\
Calcium hydroxide Day I & $0.045^{*}$ & - & - & - & $0.000^{*}$ & $0.000^{*}$ \\
Calcium hydroxide Day 3 & - & $0.000^{*}$ & - & $0.000^{*}$ & - & 0.443 \\
Calcium hydroxide Day 7 & - & - & $0.024^{*}$ & $0.000^{*}$ & 0.443 & - \\
\hline
\end{tabular}

Note: *Significant $(P<0.05)$.

hydroxide, and concentration of $0.1 \mathrm{microgram} / \mathrm{mL}$ was chosen because it has more than $60 \%$ viable cells. In this study we found that $0.1 \mathrm{microgram} / \mathrm{mL}$ of calcium hydroxide promotes the expressions of APAF-1, caspase-3 and caspase-9.

Apoptosis is a usual form of programmed cell death process that participates in homeostatic control of cell population, without inflammation take place. ${ }^{16}$ Apoptosis is sophisticatedly managed and balanced mechanism which helps in the elimination of unfavorable cells throughout every organism's life cycle. ${ }^{17}$ Apoptosis is initiated by an intrinsic (classical or mitochondrial) pathway and an extrinsic (death receptor or cytoplasmic) pathway. ${ }^{18}$ Both pathways converge in the final apoptotic execution phase, which is marked by nuclear DNA breakdown, protein cleavage, and apoptotic cell identification by phagocytic cells. ${ }^{19}$

Any condition or stimuli to a cell's environment is capable to induce apoptotic signaling. ${ }^{20}$ Cells experiencing apoptosis release extracellular vesicles, such as apoptotic bodies, micro-vesicles, and apoptotic exosomes, which roles in immune responses and inflammation, as an active communication from dying cells to surrounding living cells. ${ }^{17}$ Defected or dysregulation in apoptotic pathways may lead towards various malignancies and diseases, including AIDS, diabetes, and neurodegenerative diseases involving the perturbation of genes. ${ }^{21}$ 
Apoptosis is influenced by many signals interdependently. In intrinsic apoptotic pathway there are other influencing factors, such as the effector proteins BAK and BAX, antiapoptotic proteins (A1, Mcl-1, Bcl-xL, Bcl-w, and Bcl-2) and proapoptotic BH3-only proteins (Puma, Noxa, Bid, Bad, Bik, Bmf, Bim, and Hrk). ${ }^{22}$ Active BAX and BAK induce mitochondrial outer-membrane permeabilization (MOMP), and initiates cytochrome c efflux, which form a complex with APAF-1 and activate caspase-9 to activate caspase$3 .^{23}$ In extrinsic apoptotic pathway there are influencing factors, such as TNF receptor superfamily (TNF alpha, FAS and TRAIL receptors), cytosolic death domains (DD) receptors to bind TNFR-associated death domain (TRADD) or Fas-associated death domain (FADD), and finally form a death-inducing signaling complex (DISC), which would activate caspase- 3 , caspase- 6 and caspase- $7 .{ }^{17}$

APAF-1 (Apoptotic protease activating factor 1) is normally present in cytoplasm in inactive form, and can be activated by cytochrome $\mathrm{c}$ and controlled by pro and anti-apoptotic molecules. ${ }^{19}$ APAF-1 is responsible for caspase- 9 activation. Aside from its central role in the initiation of cell death, APAF-1 have non-apoptotic functions. The non-apoptotic roles of APAF-1 are modulatory effect on cell cycle during DNA damage induced by genotoxic stress and participation in the cytoskeleton arrangement and centrosomic microtubule nucleation process. ${ }^{24}$

Caspases are a collection of proteases recognized for their important function in programmed cell death, abbreviated from cysteine-aspartic protease activity. ${ }^{19}$ Caspases have been grouped into apoptotic caspases and inflammatory caspases. According to the action mechanism, apoptotic caspases are classified into initiator caspases and executioner caspases. Caspase-3 and caspase- 9 belong to the apoptotic caspase group; caspase- 3 is an executioner and caspase- 9 is an initiator. $^{17}$

Caspase-3, a pivotal role in apoptosis, is a downstream effector and is affected by intrinsic and extrinsic pathways. ${ }^{25,26}$ Various stimuli can affect the apoptosis. Calcium ion plays a crucial role in the intrinsic apoptotic pathway: high regulation of calcium into mitochondria lead to the deliverance of cytochrome c. ${ }^{16}$ In the cytoplasm, cytochrome $\mathrm{c}$ ties to a cytoplasmic protein known as APAF-1 and shapes the apoptosome that initiates procaspase-9 into caspase-9 and then triggers other caspases that will eventually execute cell disintegration. ${ }^{27}$

Increased expression of APAF-1 would mean increased levels of apoptosis. Caspase 9 would turn on pro-caspase-3 into caspase-3 as a caspase effector which conveys apoptosis. ${ }^{28}$ The quantity of APAF-1 and procaspase-9 affect the proportion of caspase- 9 homodimers and heterodimers shaped in the apoptosome. ${ }^{29}$

Previous reports demonstrated that mitochondrial caspases in intrinsic apoptosis have several non-apoptotic roles, including cellular reprogramming, differentiation, immunogenic, and proliferation. ${ }^{23}$ Most caspases have roles in cell proliferation, survival, inflammation, or differentiation. ${ }^{25}$ Other than lethal function in apoptosis, caspase-3 and caspase-9 have non-lethal function in cell differentiation, with caspase- 3 having more functions in cell maturation and activation. ${ }^{23}$ Caspase- 3 has a vital role in tissue regeneration, differentiation, and neural development differently and not involving apoptotic activity. ${ }^{30}$

In this study, the addition of calcium hydroxide was correlated with high expression of APAF-1, caspase-3, and caspase-9, but these intense expressions are also happened to the control groups. HUCMSCs experience apoptosis on its own timing, but the addition of calcium hydroxide accelerated HUCMSCs to apoptosis. Calcium hydroxide trigger the mitochondrial apoptosis. This trigger might not only cause apoptosis but might also have a function in immune defense mechanism. ${ }^{17}$ The increased apoptosis in this study may imply clinical practice during regenerative endodontic procedures. In this case, it may have roles in stem cell proliferation, survival, or differentiation. Another study involving calcium hydroxide provided that it upregulates HUCMSCs interleukin-10 expression and osteogenic differentiation. ${ }^{31}$ As this research is an in vitro study, there are limitations. Therefore, we should also explore at broader potential aspects or biomarkers other than apoptosis.

However, apoptosis is needed for homeostasis and pathological processes. ${ }^{22}$ Previous reports showed that, during apoptosis, cells sustain the integrity of the plasma membrane to prevent inflammation. ${ }^{8}$ This study indicates evidence regarding HUCMSCs apoptosis induced by calcium hydroxide. Appropriate apoptosis of HUCMSCs is advantageous for tissue regeneration.

\section{Conclusion}

In conclusion, although HUCMSCs has a high proliferation capacity and anti-inflammation capacity, this study provides evidence that calcium hydroxide promotes HUCMSCs to apoptosis, even if it was administered in non-toxic dose. Further studies are needed to know more about HUCMSCs use in regenerative dental procedures. 


\section{Acknowledgments}

The authors would like to thank Lembaga Pengelola Dana Pendidikan Kementerian Keuangan Republik Indonesia, Faculty of Medicine, and Faculty of Dental Medicine Universitas Airlangga for the given technical supports.

\section{Disclosure}

The authors report no conflicts of interest in this work.

\section{References}

1. Rajabzadeh N, Fathi E, Farahzadi R. Stem cell-based regenerative medicine. Stem Cell Investig. 2019;6:19. doi:10.21037/sci.2019.06.04

2. Meguid EA, Ke Y, Ji J, El-Hashash AHK. Stem cells applications in bone and tooth repair and regeneration: new insights, tools, and hopes. J Cell Physiol. 2017;9999:1-11. doi:10.1002/jcp.25940

3. Li T, Xia M, Gao Y, Chen Y, Xu Y. Human umbilical cord mesenchymal stem cells: an overview of their potential in cell-based therapy. Expert Opin Biol Ther. 2015;15:1293-1306. doi:10.1517/ 14712598.2015.1051528

4. Subramanian A, Fong CY, Biswas A, Bongso A. Comparative characterization of cells from the various compartments of the human umbilical cord shows that the Wharton's jelly compartment provides the best source of clinically utilizable mesenchymal stem cells. PLoS One. 2015;10(6):e0127992. doi:10.1371/journal.pone.0127992

5. Ba-Hattab R, Al-Jamie M, Aldreib H, Alessa L, Alonazi M. Calcium hydroxide in endodontics: an overview. Open $J$ Stomatol. 2016;6:274-289. doi:10.4236/ojst.2016.612033

6. Kahler B, Chugal N, Lin LM. Alkaline materials and regenerative endodontics: a review. Materials. 2017;10:1389. doi:10.3390/ ma10121389

7. Prasetyo EP, Widjiastuti I, Cahyani F, et al. Cytotoxicity of calcium hydroxide on human umbilical cord mesenchymal stem cells. Pesqui Bras Odontopediatria Clin Integr. 2020;20:e044. doi:10.1590/ pboci.2020.149

8. Wu T, Li L, Du R, Jiang L, Zhu Y. Hydrogen peroxide induces apoptosis in human dental pulp cells via caspase-9 dependent pathway. J Endod. 2013;39(9):1151-1155. doi:10.1016/j.joen.2013. 06.006

9. Fathi E, Valipour B, Sanaat Z, Charoudeh HN, Farahzadi R. Interleukin-6, -8 , and TGF-b secreted from mesenchymal stem cells show functional role in reduction of telomerase activity of leukemia cell via Wnt5a/b-catenin and P53 pathways. Adv Pharm Bull. 2020;10(2):307-314. doi:10.34172/apb.2020.037

10. Mobarak H, Fathi E, Farahzadi R, Zarghami N, Javanmardi S. L-carnitine significantly decreased aging of rat adipose tissue-derived mesenchymal stem cells. Vet Res Commun. 2017;41:41-47. doi:10.1007/s11259-016-9670-9

11. Kuntjoro M, Prasetyo EP, Cahyani F, et al. Lipopolysaccharide's cytotoxicity on human umbilical cord mesenchymal stem cells. Pesqui Bras Odontopediatria Clin Integr. 2020;20:e048. doi:10.1590/pboci.2020.153

12. Farahzadi R, Fathi E, Vietor I. Mesenchymal stem cells could be considered as a candidate for further studies in cell-based therapy of Alzheimer's disease via targeting the signaling pathways. ACS Chem Neurosci. 2020;11:1424-1435. doi:10.1021/acschemneuro.0c00052

13. Jensen EC. Quantitative analysis of histological staining and fluorescence using ImageJ. Anatomical Record. 2013;296:378-381. doi:10. 1002/ar.22641

14. Deng Y, Zhang Y, Ye L, et al. Umbilical cord-derived mesenchymal stem cells instruct monocytes towards an IL10-producing phenotype by secreting IL6 and HGF. Sci Rep. 2016;6:37566. doi:10.1038/ srep37566
15. Nugraha AP, Prasetyo EP, Kuntjoro M, et al. The effect of cobalt (II) chloride in the viability percentage and the induced hypoxia inducible factor-1a of human adipose mesenchymal stem cells (HAMSCs): an in vitro study. Sys Rev Pharm. 2020;11(6):308-314. doi:10.31838/ srp.2020.6.49

16. Kontogiannis TG, Tosios KI, Kerezoudis NP. Effect of calcium hydroxide as intracanal medicament on the expression of caspase- 9 located within the radicular cyst epithelium. Aust Endod J. 2019;1-5. doi:10.1111/aej.12325

17. Kakarla R, Hur J, Kim YJ, Kim J, Chwae Y. Apoptotic cell-derived exosomes: messages from dying cells. Exp Mol Med. 2020;52:1-6. doi:10.1038/s12276-019-0362-8

18. Rogers C, Fernandes-Alnemri T, Mayes L, Alnemri D, Cingolani G, Alnemri ES. Cleavage of DFNA5 by caspase-3 during apoptosis mediates progression to secondary necrotic/pyroptotic cell death. Nat Commun. 2017;8:14128. doi:10.1038/ ncomms 14128

19. Cavalcante GC, Schaan AP, Cabral GF, et al. A cell's fate: an overview of the molecular biology and genetics of apoptosis. Int $J \mathrm{Mol}$ Sci. 2019;20:4133. doi:10.3390/ijms20174133

20. Brokatzky D, Dorflinger B, Haimovici A, et al. A non-death function of the mitochondrial apoptosis apparatus in immunity. EMBO J. 2019;38:e100907. doi:10.15252/embj.2018100907

21. Arif M, Syed A, Mahmood A, Khan S, Rizwan M, Munir A. Modelling of apoptosis through gene interaction network and analysis of gene expression pattern. Meta Gene. 2020;25:100730. doi:10.1016/j.mgene.2020.100730

22. Lamb HM. Double agents of cell death: novel emerging functions of apoptotic regulators. FEBS J. 2020;287:2647-2663. doi:10.1111/ febs. 15308

23. McArthur K, Kile BT. Apoptotic caspases: multiple or mistaken identities. Trends Cell Biol. 2018;28(6):475-493. doi:10.1016/j. tcb.2018.02.003

24. Shakeri R, Kheirollahi A, Davoodi J. Apaf-1: regulation and function in cell death. Biochimie. 2017;135:111-125. doi:10.1016/j. biochi.2017.02.001

25. Aydogan A, Kocer G, Ozmen O, Kocer M, Onal L, Koskan O. Immunohistochemical expression of caspase-3, caspase-5, caspase-7 and apoptotic protease-activating factor-1 (APAF-1) in the liver and kidney of rats exposed to zoledronic acid (ZOL) and basic fibroblast growth factor (bFGF). Vet Q. 2014;34(3):137-142. doi:10.1080/ 01652176.2014.928759

26. Pradeep AR, Suke DK, Prasad MVR, et al. Expression of key executioner of apoptosis caspase-3 in periodontal health and disease. J Investig Clin Dent. 2016;7:174-179. doi:10.1111/ jicd. 12134

27. Taylor RC, Cullen SP, Martin SJ. Apoptosis: controlled demolition at the cellular level. Nat Rev Mol Cell Biol. 2008;9:231-241. doi: $10.1038 / \mathrm{nrm} 2312$

28. Nandarani RE, Widjiastuti I, Mooduto L. Pulp fibroblast cell apoptosis after application of hema dentine bonding material with ethanol and water solvent. Braz Dent J. 2019;30(3):208-212. doi:10.1590/ 0103-6440201902524

29. Wu C, Lee S, Malladi S, et al. The apaf-1 apoptosome induces formation of caspase-9 homo- and heterodimers with distinct activities. Nat Commun. 2016;7:13565. doi:10.1038/ncomms13565

30. Shalini S, Dorstyn L, Dawar S, Kumar S. Old, new and emerging functions of caspases. Cell Death Differ. 2015;22:526-539. doi:10.1038/cdd.2014.216

31. Prasetyo EP, Kuntjoro M, Cahyani F, et al. Calcium hydroxide upregulates interleukin-10 expression in time dependent exposure and induces osteogenic differentiation of human umbilical cord mesenchymal stem cells. Int J Pharm Res. 2021;13(1):140-145. doi:10.31838/ijpr/2021.13.01.023 


\section{Publish your work in this journal}

Clinical, Cosmetic and Investigational Dentistry is an international, peer-reviewed, open access, online journal focusing on the latest clinical and experimental research in dentistry with specific emphasis on cosmetic interventions. Innovative developments in dental materials, techniques and devices that improve outcomes and patien satisfaction and preference will be highlighted. The manuscript management system is completely online and includes a very quick and fair peer-review system, which is all easy to use. Visit http://www.dovepress.com/testimonials.php to read real quotes from published authors. 